\title{
26 December 2004 tsunami deposits left in areas of various tsunami runup in coastal zone of Thailand
}

\author{
Witold Szczuciński ${ }^{1}$, Grzegorz Rachlewicz ${ }^{2}$, Niran Chaimanee ${ }^{3}$, Darunee Saisuttichai ${ }^{4}$, \\ Thawatchai Tepsuwan ${ }^{4}$, and Stanisław Lorenc ${ }^{1}$ \\ ${ }^{1}$ Institute of Geology, Adam Mickiewicz University in Poznań, Maków Polnych 16, 61-606 Poznań, Poland \\ ${ }^{2}$ Institute of Geoecology and Geoinformation, Adam Mickiewicz University in Poznań, Dzięgielowa 27, 61-680 Poznań, Poland \\ ${ }^{3}$ Coordinating Committee for Geoscience Programmes in East and Southeast Asia, Bangkok 10120, Thailand \\ ${ }^{4}$ Department of Mineral Resources, Bangkok 10400, Thailand
}

(Received December 13, 2010; Revised March 4, 2012; Accepted July 19, 2012; Online published October 24, 2012)

\begin{abstract}
The tsunami deposits left by the 26 December 2004 tsunami in the coastal zone of Thailand were studied within two months of the event and before any significant postdepositional changes could occur. The sediment structure and texture (grain size), as well as its thickness and spatial distribution, were documented for the tsunami deposits in 12 shore-perpendicular transects from areas of various tsunami runup and wave heights. The tsunami deposits were as thick as $0.4 \mathrm{~m}$ and were located as far as $1.5 \mathrm{~km}$ inland. They were composed mostly of poorly sorted sand and often consisted of one to four normally graded, massive or laminated layers. The deposits generally became finer in the landward direction; however, landward thinning trend of the deposits is not clear, and the maximum accumulation often is not located close to the shoreline but rather is further inland. In comparable coastal environments with similar available sediment sources the tsunami size (represented as the tsunami runup height) is reflected in the resulting deposits. Larger tsunamis are associated with deposits that are thicker, have a maximum accumulation located farther inland, include a finer sediment fraction (likely from deeper offshore areas) and frequently are composed of normally graded layers.
\end{abstract}

Key words: Tsunami deposits, 2004 Indian Ocean tsunami, tsunami runup, grain size, sedimentation, event deposits, Thailand, Andaman Sea.

\section{Introduction}

Tsunami waves often leave a fingerprint in a coastal zone in the form of sedimentary event deposits (Shiki et al., 2008; Bourgeois, 2009). During the last 15 years, much effort has been devoted to documenting the various recent tsunami deposits (Nishimura and Miyaji, 1995; Sato et al., 1995; Shi et al., 1995; Dawson et al., 1996; Minoura et al., 1997; Bourgeois et al., 1999; Gelfenbaum and Jaffe, 2003; Nanayama and Shigeno, 2006; Higman and Bourgeois, 2008; Goto et al., 2011; Moore et al., 2011). The majority of these works focused on documentation of the 2004 Indian Ocean Tsunami (IOT) depositional effects along the coasts of Sumatra (Moore et al., 2006; Razzhigaeva et al., 2006; Richmond et al., 2006; Paris et al., 2007, 2009), Thailand (Hori et al., 2007; Kelletat et al., 2007; Choowong et al., 2008a, b; Matsumoto et al., 2008; Sawai et al., 2009; Fujino et al., 2010; Naruse et al., 2010), Sri Lanka (Morton et al., 2008), India (Bahlburg and Weiss, 2007; Srinivasalu et al., 2007) and Maldives (Kench et al., 2006).

There are two main reasons supporting the need for those studies. The first is to provide good diagnostic criteria to help identify paleotsunami deposits, which are necessary to improve the tsunami hazard assessment for a given coast

Copyright (C) The Society of Geomagnetism and Earth, Planetary and Space Sciences (SGEPSS); The Seismological Society of Japan; The Volcanological Society of Japan; The Geodetic Society of Japan; The Japanese Society for Planetary Sciences; TERRAPUB.

doi:10.5047/eps.2012.07.007 (e.g. Clague et al., 2000; Nanayama et al., 2007; Jankaew et al., 2008). The explicit identification of paleotsunami deposits is often difficult mainly because the tsunami deposits may be represented by various sediment types and may be similar to other deposits, such as storm deposits (Morton et al., 2007; Switzer and Jones, 2008). Until now, there has been no simple universal diagnostic set of criteria that can be applied to analyse tsunami deposits with certainty (Dawson and Shi, 2000; Goff et al., 2001; Scheffers and Kelletat, 2003; Shiki et al., 2008; Bourgeois, 2009; Chagué-Goff, 2010; Peters and Jaffe, 2010; Chagué-Goff et al., 2011; Goff et al., 2012). The second reason to study the recent tsunami deposits is to potentially gain insight into the processes and forces that exist during the tsunami inundation. For instance, the studies of the tsunami deposits may be used to assess the water flow velocity and the depth of tsunami inundations. These studies can also identify how the tsunami affected the coastal geomorphology (Jaffe and Gelfenbaum, 2007; Smith et al., 2007; Paris et al., 2009). They are also necessary for the validation of tsunami sediment transport models.

The tsunami deposits were documented by several research teams in the field within a few months after the IOT in parts of the Andaman Sea coastal zone of Thailand. The published results include works focused on the overall geological impacts of the tsunami (Szczuciński et al., 2006; Choowong et al., 2007; Kelletat et al., 2007; Umitsu et al., 2007), on the detailed analyses of sedimentary prop- 
erties of sandy deposits (Hori et al., 2007; Choowong et al., 2008a, b; Fujino et al., 2008, 2010; Goto et al., 2008; Matsumoto et al., 2008; Alam, 2010; Naruse et al., 2010) and on the boulder deposits (Goto et al., 2007; Yawsangratt et al., 2009). Also studied were specific aspects such as the micropaleontological features of the deposits (Hawkes et al., 2007; Kokociński et al., 2009; Sawai et al., 2009; Yawsangratt et al., 2012), their geochemistry (Szczuciński et al., 2005; Boszke et al., 2006; Kozak et al., 2008; ZiołaFrankowska et al., 2009), their physical properties (Bishop et al., 2005) and their mineralogy (Jagodziński et al., 2009). The IOT deposits were also presented in papers focused on paleotsunami deposits (Jankaew et al., 2008, 2011; Fujino et al., 2009; Brill et al., 2011; Yawsangratt et al., 2012). The aforementioned works revealed that the IOT deposits varied considerably regarding extent, thickness, grain size (mud to boulders), internal structures, composition and preservation potential. The deposits usually formed extensive sand sheets with a thickness ranging from a few $\mathrm{cm}$ to several tens of $\mathrm{cm}$. They were commonly layered and normally graded, with evidence of both onshore and backwash flows, and some components suggested origins from marine, brackish and terrestrial environments. While many works were published, the detailed sedimentological data have not yet been reported from the present study areas, particularly the Patong Bay area and Kho Khao Island. Most of the previous studies are limited in the number of observations (usually one or two transects or trenches). Furthermore, the studies made no attempts to compare deposits left in areas of relatively similar topography and potential source sediments that experienced varied height of tsunami runup. Several studies were also conducted one or more years after a tsunami. However, they are not discussed here because they have not assessed the post-depositional changes that were found to be important in the case of the onshore tsunami deposits in Thailand (Szczuciński et al., 2006, 2007; Goto et al., 2008, 2012; Jankaew et al., 2008; Szczuciński, 2012), as well as in other parts of the Indian Ocean basin (Nichol and Kench, 2008).

This paper has four objectives:

- to provide a new documentation of the recent (i.e., not altered by post-depositional processes) onshore tsunami deposits (spatial extent, thickness, sediment structure and texture) from areas flooded by the 2004 IOT that experienced various runup heights,

- to interpret the possible tsunami-related sedimentation processes,

- to examine if variations in the tsunami runup heights are reflected in the tsunami deposit properties

- and to compare the new data with the existing common set of diagnostic features for tsunami deposits.

\section{Study Area and 2004 IOT}

This study was conducted in the coastal zone of western Thailand (Phang Nga province and Phuket Island), which faces the Andaman Sea (Fig. 1). The studied sites represent either the rocky shorelines with small pocket beaches and narrow coastal plains (on Phuket Island: Tri Trang, Patong) or the long sandy beaches that are flanked by coastal plains as wide as $3 \mathrm{~km}$ (in Phang Nga province: Bang Sak, Bang
Mor, Kho Khao Island). The coastal plain is undulated because of its formation processes (beach ridges and swales) as well as human activity (tin mining). The region is characterised by a warm climate with approximately $3000 \mathrm{~mm}$ of precipitation per year that primarily falls during the rainy season (May to September). The studied sites were investigated shortly after the IOT event, during the dry period, so no rainfall altered the freshly deposited tsunami sediments.

On the 26th of December 2004, at 00:58:53 universal time, an earthquake of surface wave magnitude $\left(M_{\mathrm{s}}\right) 9.0$ occurred off the west coast of northern Sumatra (Fig. 1(A)) (Lay et al., 2005) and generated tsunami waves that reached the coast of Thailand at Phuket Island approximately 100 minutes after the earthquake. The tsunami wave arrived during high tide with leading depression wave (Kawata et al., 2005; Tsuji et al., 2006). Most of the eyewitness reports documented two major waves, with a period of approximately 40 minutes, inundating the coastal zone; several smaller waves were also documented. Altogether, up to 7 waves were reported by eyewitnesses (Mård Karlsson et al., 2009). Some of the witnesses reported a smaller wave arriving a few minutes before the main wave (Mård Karlsson et al., 2009). Alternatively, some witnesses reported several waves inundating the land in periods of a few minutes without intervening water withdrawals (Choowong et al., 2008b). In general, the second wave was reported to be bigger (Kawata et al., 2005).

The tsunami waves inundated the research areas to various extents in relation to tsunami size, offshore bathymetry and coastal zone topography (Szczuciński et al., 2006). The inundation distance varied from a few hundred meters to more than one kilometer inland (Fig. 1). For areas with averaged slope inclination of 1.5 to $3 \%$ (most common in the studied case), the inundation was partly correlated with slope inclination and runup height - generally shorter inundation distance and higher runup was in observed on steeper slopes (Szczuciński et al., 2006). The tsunami runup height at the maximum inundation limit usually varied from less than $3 \mathrm{~m}$ in the part of Kho Khao Island's coast, which is protected by an offshore reef, to more than $6 \mathrm{~m}$ in northern and southern Kho Khao Island and in Ban Bang Mor (Fig. 1(C)). Although the runup heights were partly controlled by topography, the areas of the highest runup $(>6 \mathrm{~m})$ coincided also with the sites where the highest wave height ( tsunami flow depth) was reported. Tsuji et al. (2006) documented wave height to be over $12 \mathrm{~m}$ above sea level from the northern Kho Khao Island and over $15 \mathrm{~m}$ from its southern part and from the coast southward from the island (Ban Nham Kem). Tsunami wave height of more than $15 \mathrm{~m}$ was also reported from Pakarang Cape (Siripong, 2006). In the areas with smaller runup heights $(<6 \mathrm{~m})$ the wave heights measured close to the studied transects were up to $6.4 \mathrm{~m}$ (Tsuji et al., 2006). The tsunami wavefront water velocity, calculated from the videos of the tsunami, was estimated to reach $14.4 \mathrm{~km} \mathrm{~h}^{-1}$ in Phuket (Kawata et al., 2005) and $33 \pm 4 \mathrm{~km} \mathrm{~h}^{-1}$ in Khao Lak (Mård Karlsson et al., 2009). 


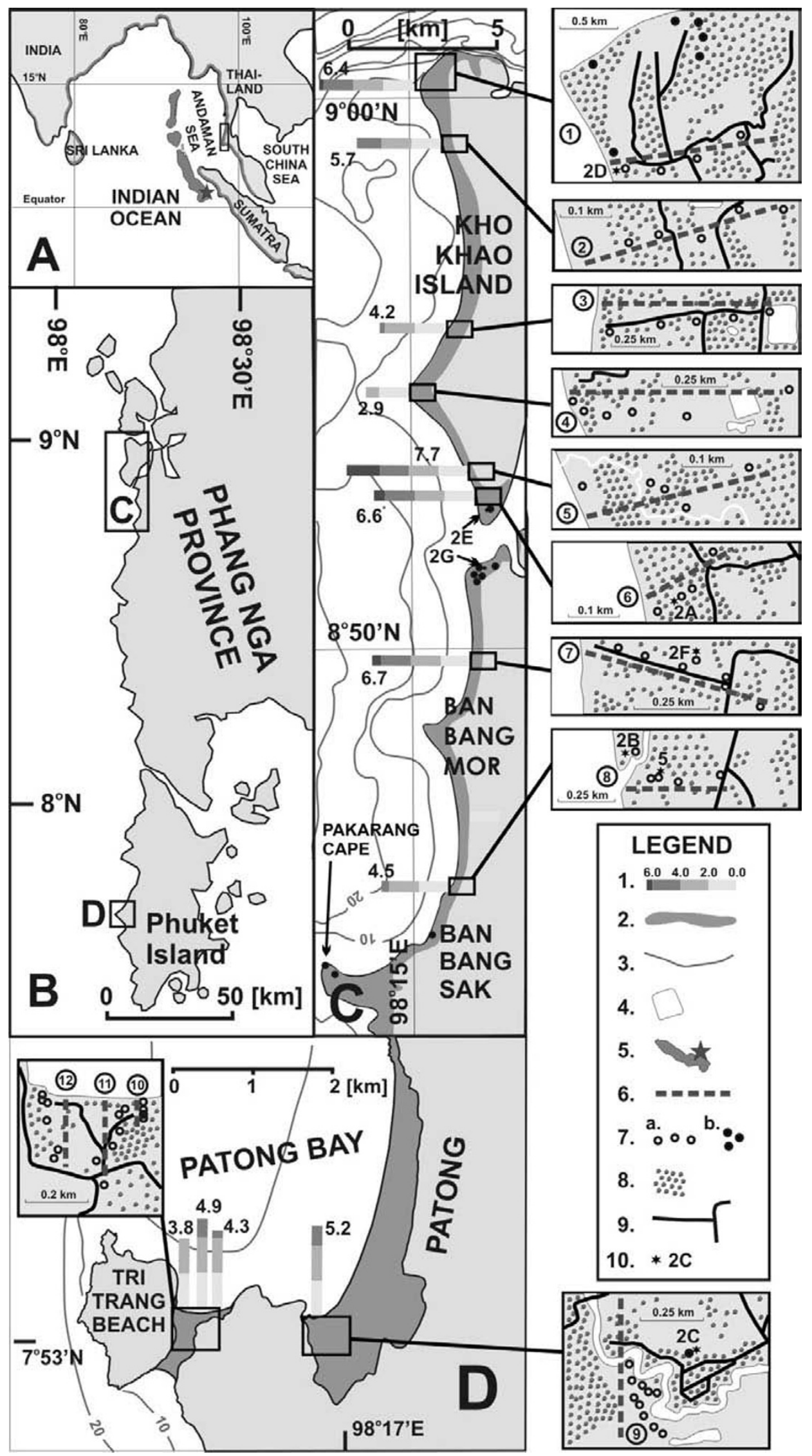

Fig. 1. The study area. (A) Coasts affected by IOT (bold line) and the location of the study area (in rectangle); (B) Part of the Andaman Sea coast of Thailand with marked surveyed areas. (C-D) Location of the studied sites, measured tsunami runup heights and inundation distances (after Szczuciński et al., 2006). Legend: (1) runup height [m], (2) inundated areas, (3) offshore contour lines, (4) inland water bodies, (5) earthquake epicenter and major rupture areas during the 2004 Sumatra-Andaman earthquake (after Subarya et al., 2006), (6) topographical transect lines presented in Figs. 3 and 4, (7) investigated trenches, (a) included in transects (Figs. 3 and 4); (b) remaining investigated sites, (8) forests, (9) roads, (10) sites shown in Fig. 2. 


\section{Materials and Methods}

The field study was carried out in January and February 2005 , less than two months after the tsunami. At the time of the survey, the tsunami deposits were almost unaltered given that no rain was reported between the tsunami and the sampling. The investigations were preceded by a geodetic survey with differential GPS (Leica SR530 GPS System 500) to document the inundated zone morphology and the tsunami runup. The runup is defined as the difference between the elevations of the maximum tsunami penetration and the elevation of the shoreline at the time of the tsunami, which was corrected for the tidal phase difference between the time of the measurement and of the tsunami (Intergovernmental Oceanographic Commission, 2008). The details for the applied correction procedure are documented in Szczuciński et al. (2006), and the tide gauge records from the time of the tsunami are from Tsuji et al. (2006). A handheld Garmin GPS was used to document the position of each sampling site.

The tsunami deposits were investigated in more than 80 pits (Fig. 1), usually located in the shoreline normal transects. Apart from the beach zone sites, which are not included in this paper, the identification of the deposits was straightforward. At each site, the thickness of the tsunami deposit was measured. In the case of significant lateral thickness variations on a pit scale, an additional control pit was dug, and the thickness was measured within the pits at equally spaced distances to report an average value. The deposits were photographed and described, taking into account the surface forms, the relation to the underlying horizon, the internal sedimentary structures and the major sediment components. In most of the investigated sites, bulk samples of the tsunami deposits were taken. In a majority of those pits in which significant vertical grain size change was clearly observed, each individual layer was sampled separately. Some samples of beach sediments and soils or sediments underlying the tsunami deposits were also taken. Additional observations, including notes on the tsunami deposit extents and on the change in deposit thickness, were also made along the investigated transects.

All of the samples $(N=127)$ were subjected to a grain size analysis. The samples were dried and sieved into thirteen, 0.5 phi interval, grain-size fractions ranging from gravel to mud. If the mud fraction was $>5 \%$, the fraction smaller than sand ( $>4$ phi) was further analysed with an optical diffractometry method on a laser diffraction-based Mastersizer 2000 Particle Analyzer. The data for the grain size $<4$ phi are represented as weight $\%$ (sieving results). The mud fraction obtained from the wet sieving was used as $100 \%$ for the optical diffractometry analysis. The data $>4$ phi are represented as volume \%. All of the results are represented on a phi scale. The conversion of the metric scale into phi values is based on an equation:

$$
\operatorname{phi}(\Phi)=-\log _{2} D
$$

where $D$ equals the size in $\mathrm{mm}$. The grain size statistics (mean, sorting, skewness and kurtosis) were calculated using the logarithmic method of moments with Gradistat software (Blott and Pye, 2001).

\section{Results}

The characteristics of the tsunami deposits (Fig. 2) are presented in detail for twelve selected transect lines (see Fig. 1 for locations). They are presented in Figs. 3 to 6, which include data on topography, tsunami deposit thickness, sedimentary structures and grain size (mean, sorting, skewness, mud and gravel content). The data from sites separate from the transect lines are included in the datasets presented in Figs. 7 and 8 for the tsunami deposit thickness and grain size. The following subchapters summarise the sedimentary characteristics of the documented deposits.

To facilitate further discussion in the context of the variable impact of tsunami with various runup height, the studied sites from the coast of Phang Nga province (transects 1 to 8 ), which are characterised by similar coastal environments with analogous available sediment sources, were divided into two arbitrary, equally represented classes. The Phang Nga transects 2, 3, 4, and 8 are grouped into smaller runup class $(<6 \mathrm{~m})$, and transects $1,5,6$, and 7 with runup $>6 \mathrm{~m}$ into the second class (Table 1). The topography and sediment sources of transects from Phuket Island vary from the Phang Nga province coast, so they are not included in this discussion.

\subsection{Tsunami deposit extent and thickness}

Sedimentary deposits from the tsunami are found in most places where the tsunami flooding occurred and covered almost the entire inundation zone. Most deposits are in the form of continuous sand sheets or patches. Only in a very few places are boulders transported and left by the tsunami (e.g., Pakarang Cape). The tsunami deposits are usually missing in a belt 10 to $250 \mathrm{~m}$ wide next to the shoreline (Figs. 3 and 4) where erosion and/or sediment bypassing dominated. In some cases, no tsunami deposits are found close to the flooding limit. However, in places where the tsunami flooding was limited by a cliff or scarp, they tend to be relatively thick (e.g., transect 2 in Fig. 3).

The tsunami deposit thickness varies from millimeters (Fig. 2(C)) to more than $40 \mathrm{~cm}$ (Fig. 2(A)). However, in most of the trenches, it is less than $10 \mathrm{~cm}$. The thicker accumulations of the deposits tend to be localised and are found mostly in depressions and on the seaward sides of small cliffs or scarps (Figs. 3 and 4). The deposits thicker than $30 \mathrm{~cm}$ are found only in a region approximately 100 to $150 \mathrm{~m}$ from the shoreline or just next to a beach. The thickness varies a lot on the transect scale (hundreds of meters). In some transects, the deposits are thicker with distance from the shoreline, reaching a maximum value approximately $100 \mathrm{~m}$ from the shoreline, and then they irregularly become progressively thinner inland (e.g., transects 5 and 6 in Fig. 3; Fig. 7). Only in one case (transect 3, Fig. 3) is observed a continuous landward thinning trend. The local variability of the tsunami deposit thickness is related to the local topography (thinner over local elevations) and to obstacles (deposition on the leeward side of the obstacle) (Fig. 2(E), transect 2 in Fig. 3). An example of a lee side deposition is presented in Fig. 2(E), which shows a $10-\mathrm{m}$ long ridge formed by unidirectional flow on the lee side of a tree; the site is close to the southern tip of Kho Khao Island, which was crossed by the tsunami (no backwash).

The thickness of the deposits seems to be related to the 


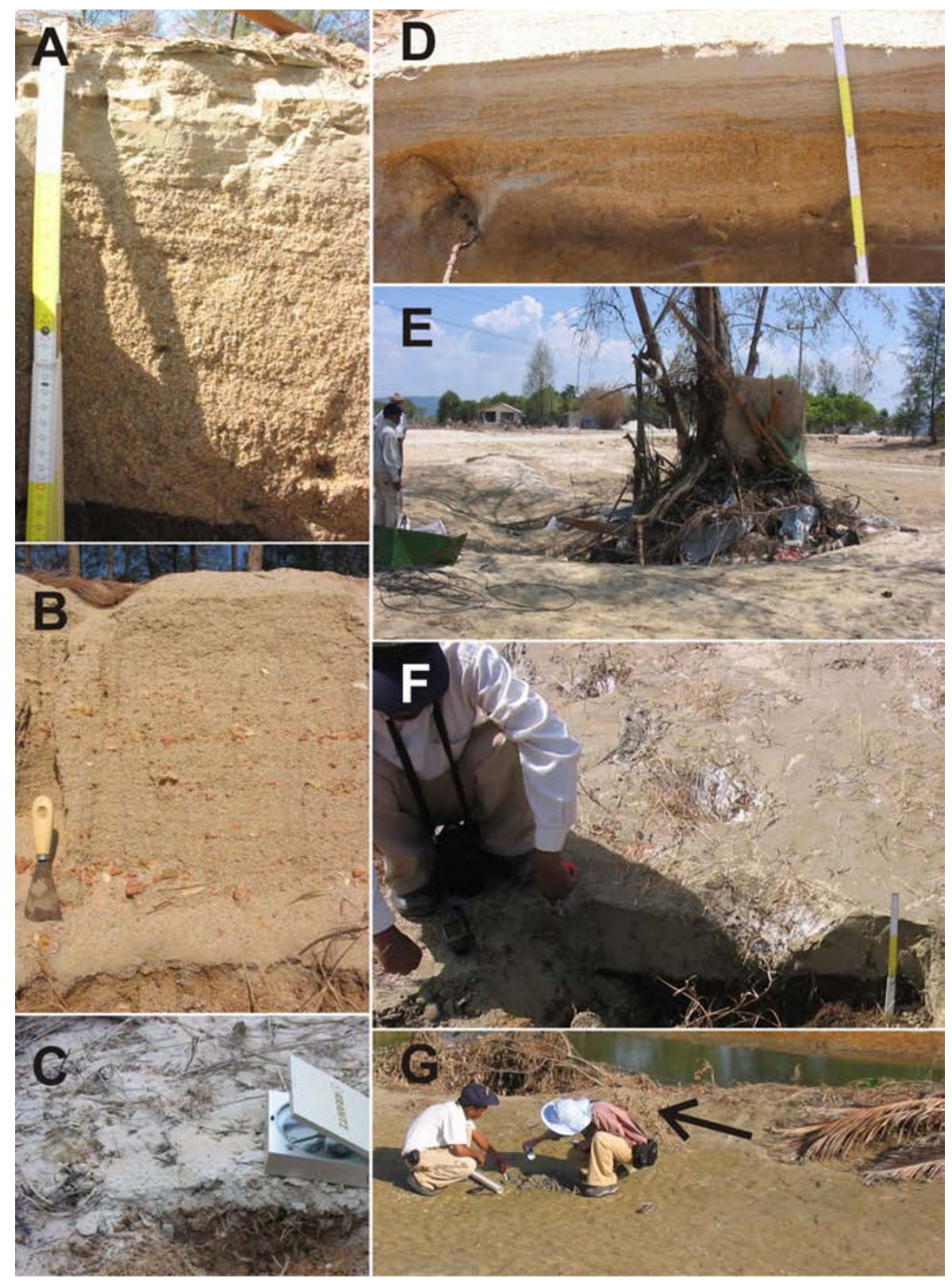

Fig. 2. Examples of IOT deposits. For locations see Fig. 1. (A) Example of 42-cm thick deposits with erosional basal contact. The deposits are composed of two units. The lower (28-cm thick) is densely laminated, moderately sorted coarse sand. The upper unit shows normally graded, poorly sorted sediments from coarse to very fine sand. (B) A 35-cm thick layer of tsunami deposits composed of very coarse sand with pieces of corals (up to $10 \mathrm{~cm}$ ). The uppermost $10 \mathrm{~cm}$ consists of coarse sand. The deposits cover former soil with still preserved bent grass. (C) Example of a 2-cm thick tsunami deposit layer composed of poorly sorted medium sand conformably covering the former soil. (D) Example of 30-cm thick tsunami deposits with lower erosional contact, composed of approximately $15 \mathrm{~cm}$ of massive coarse sand covered with a layer of densely laminated medium sand. (E) Deposition on the lee side of an obstacle (tree). The 10-m long ridge behind the tree was primarily a result of scouring and succeeding deposition, producing two normally graded layers composed of coarse to very fine sand up to 15-cm thick. (F) Circular hollows in the tsunami deposits with small ripples inside indicating rotational flow. The hollows are in a row and were possibly created by a moving vortex. The first hollow is in a 16-cm thick tsunami deposit layer composed of well-sorted, massive fine sand. The lower contact is conformable. The white cover is due to salt crust. (G) Example of an 18-cm thick layer of moderately sorted, very fine sand with preserved current ripples at the surface (landward flow direction is marked with arrow).

tsunami runup height in comparable transects from Phang Nga coast (Fig. 7, Table 1). The thickest deposits are in transects with the highest runup. The averaged tsunami deposit layer thickness for a coast with a tsunami runup height less than $6 \mathrm{~m}$ is $8.5 \mathrm{~cm}$ (29 measurements), and for the sites with a runup greater than $6.0 \mathrm{~m}, 11.4 \mathrm{~cm} \mathrm{(34}$ measurements). The trends of tsunami deposits thickness also differ with regard to the runup height (Figs. 3 and 4 , Table 1). In the case of the smaller runup transects, the maximum thickness is usually closer to the shoreline, and then the deposits generally become thinner landward (transects 3 and 4 in Fig. 3, and transect 10 in Fig. 4). In some of the areas with the highest runups, the deposit thickness increase inland until it reached approximately $1 / 3$ of the inundation distance, where the maximum is observed, and then the deposits thin landward (transects 1, 5 and 6 in Fig. 3). The fourth transect in this group (transect 7, Fig. 4) revealed three maxima, located at approximately 100, 450 


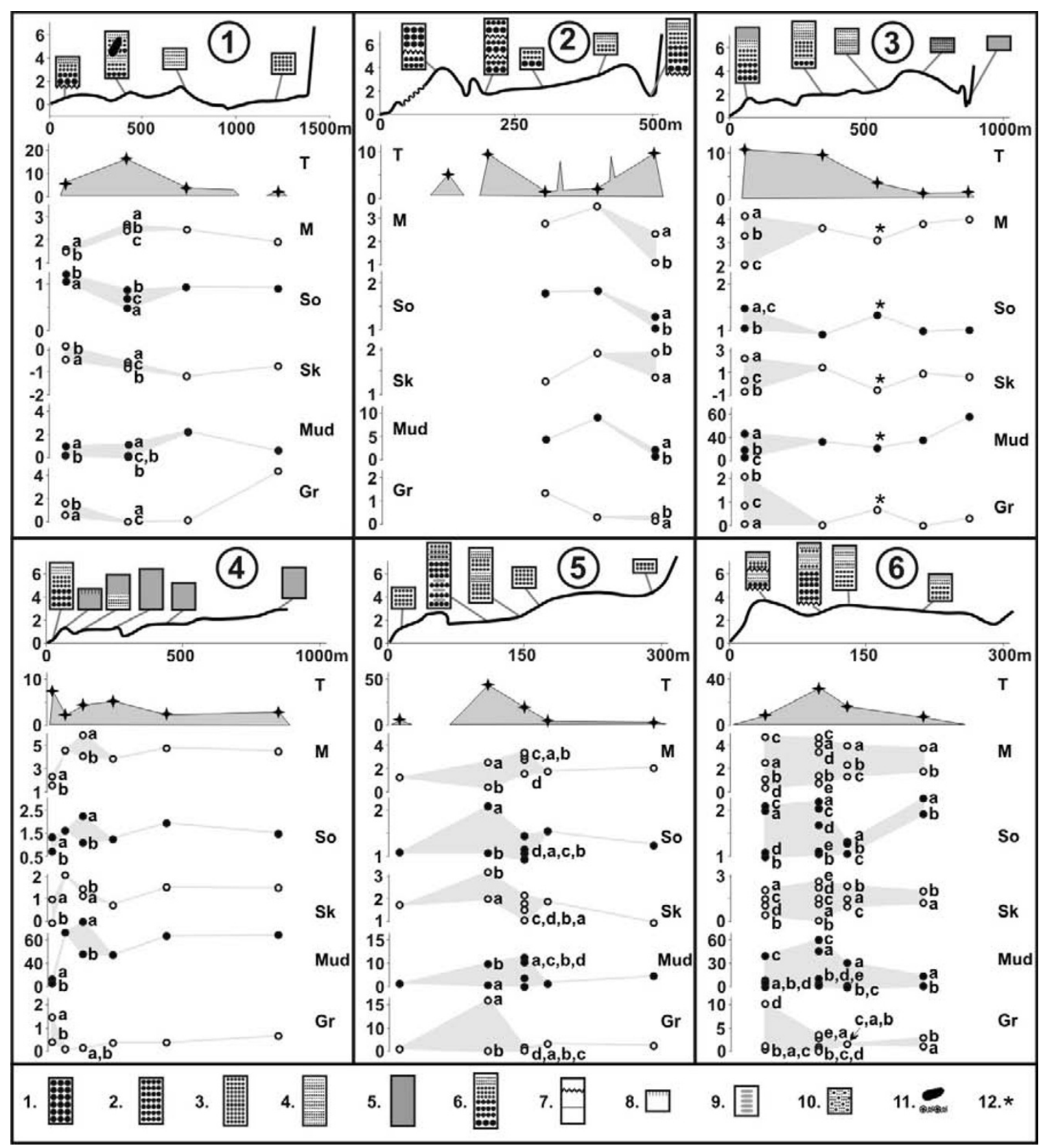

Fig. 3. Topography and tsunami deposit properties along the investigated transects. See Fig. 1 for transect locations. For each transect, the following properties are presented: shore-perpendicular morphological profile up to the inundation limit (scales in [m]) with marked locations of trenches and simplified sedimentological logs of the investigated tsunami deposits (the size of the sedimentological logs is not to scale), T-thickness of tsunami deposits (scale in [cm]), M-mean grain size of tsunami deposits (scale in [phi]; if more than one sample was investigated in a profile, the samples are marked with letters; "a" stands for the uppermost sample), So—sorting (scale in [phi]), Sk—skewness (scale in [phi]), Mud-mud fraction content (scale in weight \%) and $\mathrm{Gr}$ - gravel fraction content (scale in weight \%). Legend for the simplified sedimentological logs: (1) very coarse sand, (2) coarse sand, (3) medium sand, (4) fine sand, (5) mud, (6) normal gradation, (7) erosional contact/sharp contact, (8) desiccation structures, (9) mud clasts, (10) coral reef fragments in sand matrix, (11) concrete blocks/plant fragments and coconut detritus and (12) samples taken only from a part of the tsunami deposits profile.

and $600 \mathrm{~m}$ landward, separated by areas covered by thinner deposits. The thickest deposits are found in a depression, and their deposition was probably enhanced by the local topography.

\subsection{Tsunami deposit basal contacts}

The tsunami deposits basal contacts are usually sharp or abrupt, making the identification of the IOT fairly simple (Fig. 2). The contacts are generally plain, though also frequently irregular or undulating, and are classified as either conformable (more than $70 \%$ of the studied sites) or ero- sional (approximately 15\% of the studied sites). In approximately $15 \%$ of the studied cases, it is not possible to identify the type of contact with certainty. The conformable basal contacts are frequent when the deposits cover a previously vegetated soil and bent plants are still preserved in the IOT deposits (Figs. 2(B, C, F)). The soil texture is usually distinct and dark. In some cases, artificial anthropogenic soil is found in the form of relocated lateritic material. In many cases, the soil is relatively hard (the IOT occurred during the dry season). The erosional contacts (Fig. 2(D)) 


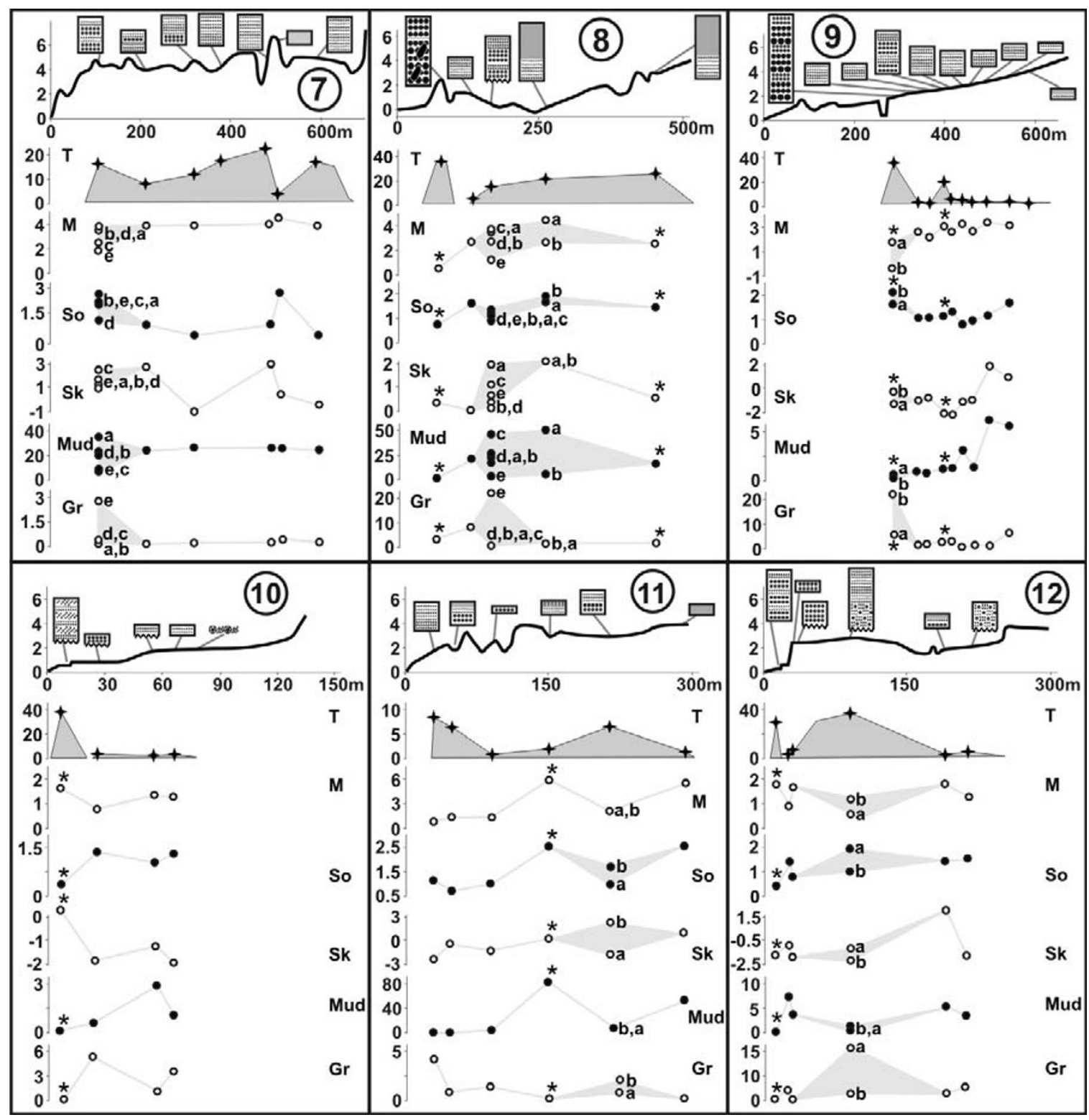

Fig. 4. Topography and tsunami deposit properties along the investigated transects. See Fig. 1 for locations. For explanations, see Fig. 3.

are found mostly in the locations closest to the shoreline (within the first $100 \mathrm{~m}$ ). Their evidence is highlighted by uprooted roots, rip up clasts and irregular contact surfaces.

\subsection{Tsunami deposit relief}

At most of the studied locations, the surface of the tsunami deposits is plain. However, in several places, there are preserved wave and current ripples (Fig. 2(G)), ridges on the lee side of obstacles (Fig. 2(E)) and rows of circular hollows (Fig. 2(F)). Wave ripples of a small amplitude, up to $3 \mathrm{~cm}$, are found at one site. Current ripple marks are much more common and are found near Nham Kem (Fig. 2(G)) and on the northern tip of Kho Khao Island. They are asymmetrical, have sinuous crests, lee side directed landward, wavelengths of 5 to $10 \mathrm{~cm}$ and heights usually less than $5 \mathrm{~cm}$. A very peculiar form is found nearby in Bang Mor, where a line of circular hollows occurs (Fig. 2(F)). They were spaced at approximately 10- to 20-m intervals and decreased in size. The largest hollows are approximately $30 \mathrm{~cm}$ in diameter and are as deep as the tsunami deposit layer (less than $20 \mathrm{~cm}$ ). The hollows are in a massive tsunami deposits layer, and no erosion of the substrate is noted. The inner sides of the hollows are covered with small ripples, suggesting a whirlpool-like water flow. The ripples and the circular hollows are documented only from the sites with a runup height of $>6 \mathrm{~m}$. In many places, the surfaces of the tsunami deposits are covered with mud cracks, organic debris (especially needles of Casuraina trees) (Fig. 2(A, C)) and salt crusts (Fig. 2(F)).

\subsection{Tsunami deposit composition}

The tsunami deposits are composed mainly of siliciclastic sand with an admixture of carbonates. In samples collected within $200 \mathrm{~m}$ of the shoreline, the sand fraction is composed of approximately $70 \%$ mostly subrounded mineral grains (quartz, feldspars, heavy minerals), approximately $25 \%$ shell fragments and approximately $5 \%$ benthic foraminifera tests. In a few areas close to the shoreline, the amount of shells and coral reef fragments is much greater. Occasionally, the deposits contain macrofauna rem- 


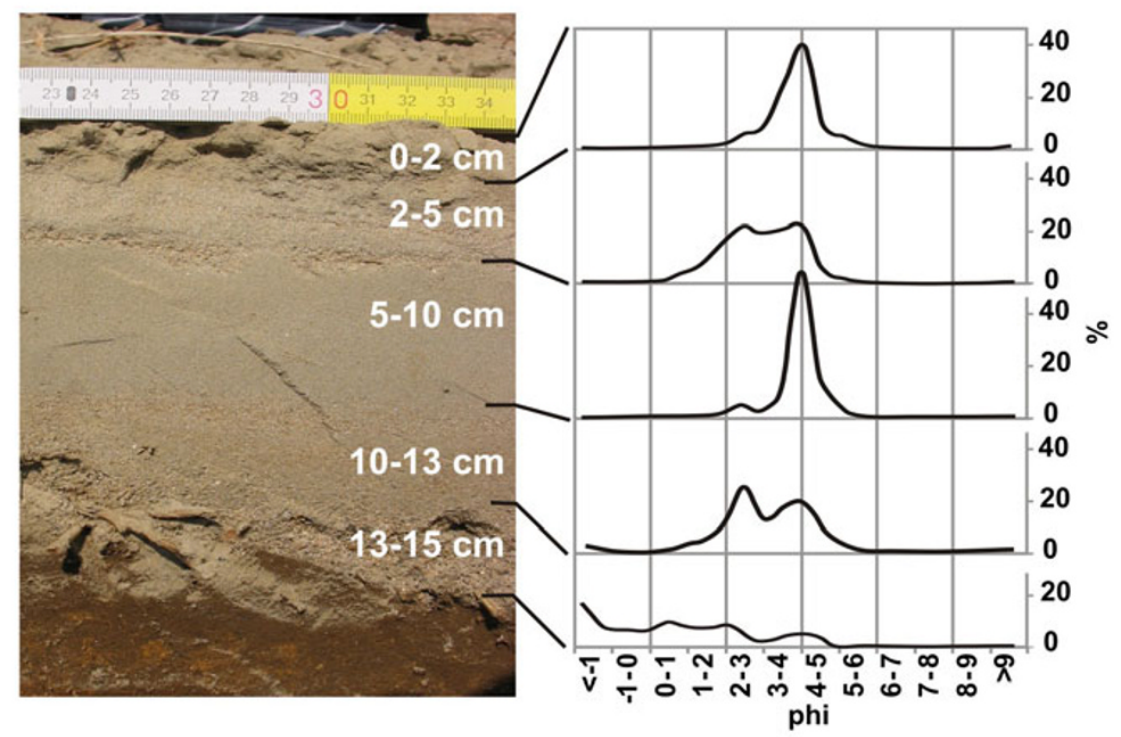

Fig. 5. Example of vertical grain size changes in tsunami deposits. Site with two normally graded layers. See Fig. 1 for location.

Transect 4 (runup $2.9 \mathrm{~m}$ )

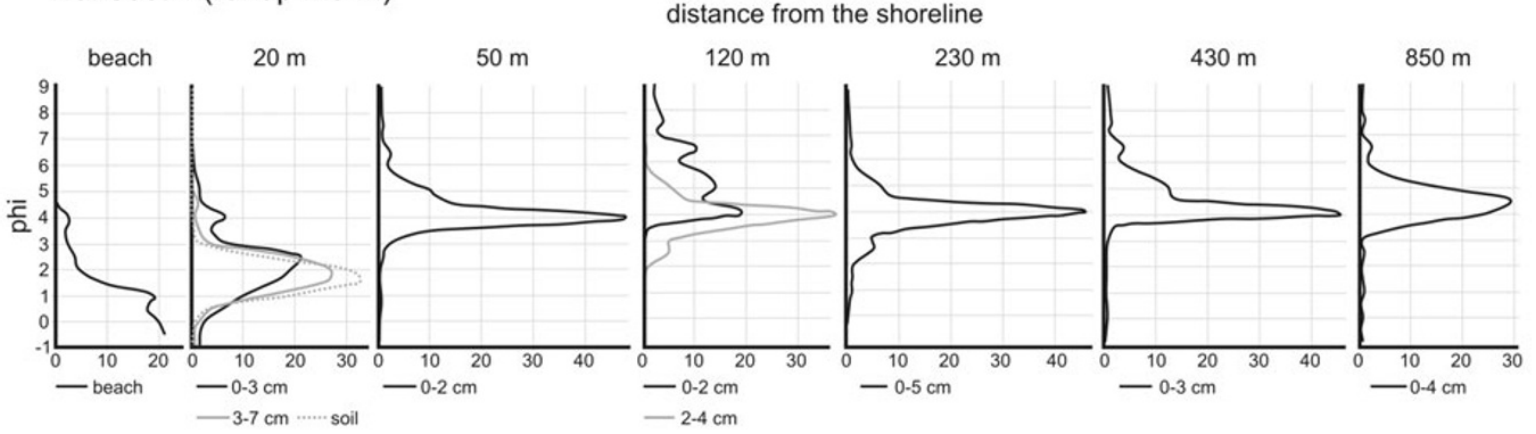

Transect 5 (runup $7.7 \mathrm{~m}$ )

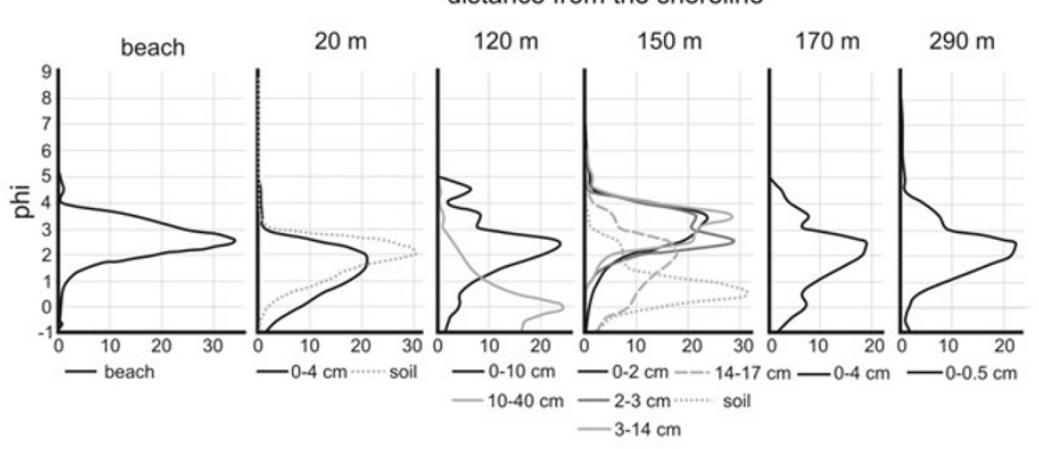

Fig. 6. Examples of lateral grain size changes in tsunami deposits in transects 4 and 5, which represent areas with low runup (2.9 m) and high runup (7.7 m), respectively.

nants (i.e., fish, turtles), grass, branches and various human artefacts (e.g., plastic). In a few cases, the IOT deposits contain the rip up clasts of older sediments. In a trench in transect 5 (Fig. 3), mud clasts more than $10 \mathrm{~cm}$ in diameter are found in a layer of almost $40 \mathrm{~cm}$ thick coarse sand. The mud clasts are of the same colour and composition as the underlying muddy sediments.

The detailed composition of a dozen or so of the samples presented here were already analysed and reported in re- gards to microfossils (Kokociński et al., 2009), heavy mineral assemblages (Jagodziński et al., 2009) and geochemistry (Szczuciński et al., 2005; Kozak et al., 2008; ZiołaFrankowska et al., 2009).

\subsection{Tsunami deposit internal structures}

Internal layering is commonly observed in the tsunami deposits that are at least a few $\mathrm{cm}$ thick. The number of layers ranges from one to four. A single layer is the most common, and two layers exist in approximately $20 \%$ of the 


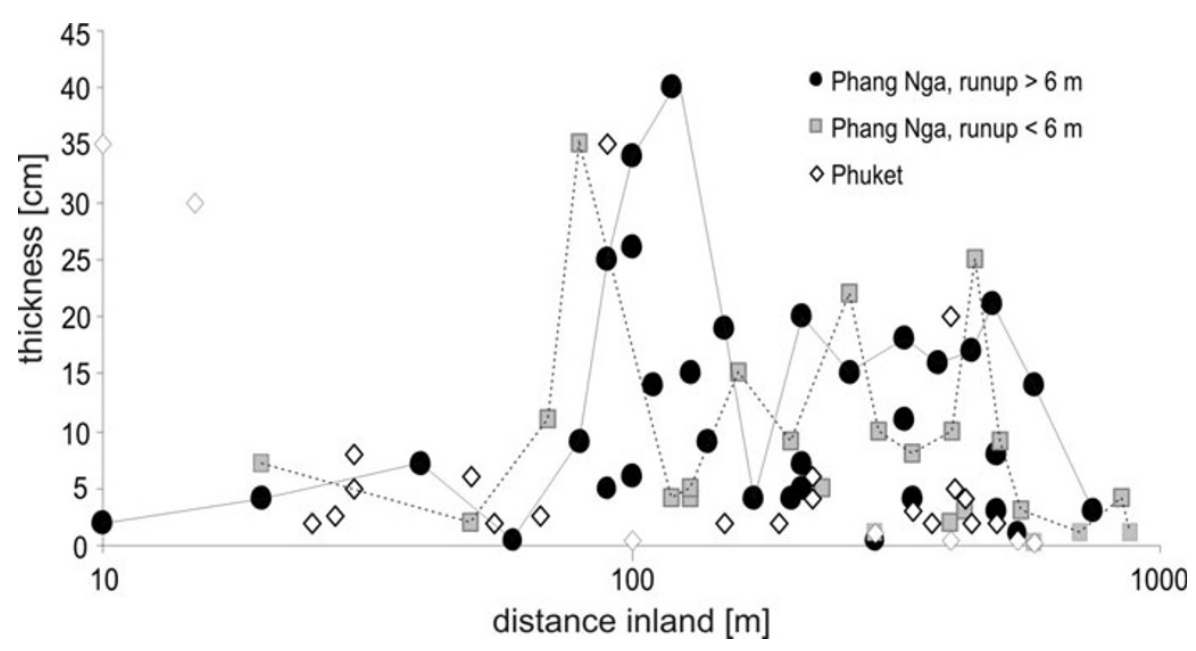

Fig. 7. Tsunami deposits thickness for $>6 \mathrm{~m}$ and $<6 \mathrm{~m}$ tsunami runup classes along Phang Nga province transects with the outline of the thickest samples plotted against the distance from the shoreline. Note the thickness maxima of higher runup class to be more inland. Data from Phuket Island transects (all $<6 \mathrm{~m}$ ) are also included. The horizontal axis is logarithmic.

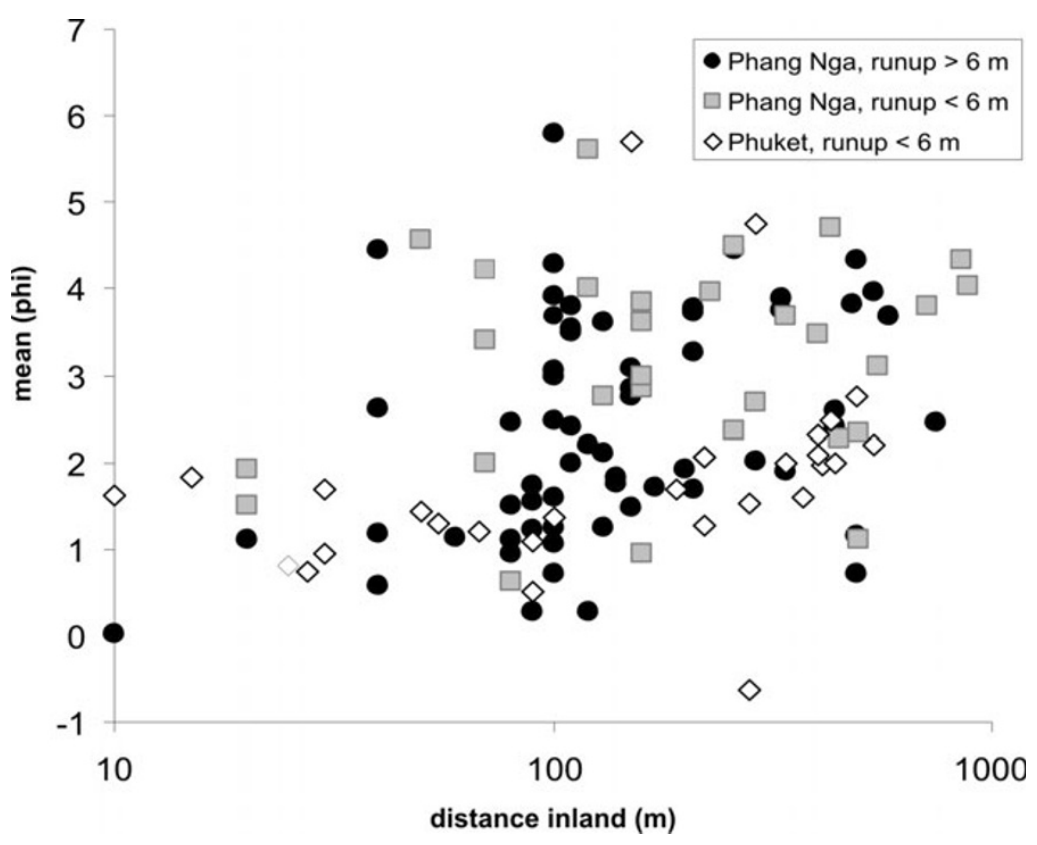

Fig. 8. Mean grain sizes of all the analysed tsunami deposits samples separated into two tsunami runup height classes plotted against the distance of the sampling points from the shoreline. The horizontal axis is logarithmic.

documented sites. Three layers are found in 3 trenches, and four layers are found at only one site. The multiple layers are generally observed in deposits thicker than $15 \mathrm{~cm}$; however, the thinnest tsunami deposits with two layers are only $4 \mathrm{~cm}$ thick. The layers are usually delineated with changes in the grain size and/or by the erosional contacts. Multiple layers are more common in transects with a runup $>6 \mathrm{~m}$ (Table 1). Regardless of the number of layers, certain beds may be massive in structure (Fig. 2(C, F)), may reveal normal grading (fining upwards) (Fig. 5), reverse grading, plane parallel lamination (Fig. 2(A, B, D)), crossbedding (Fig. 2(D)), and scour and fill structures. Within a multilayered tsunami deposit, particular layers may be of various kinds (Fig. 2(A)). The most common combination is a lower part composed of plane or cross laminated sands, reverse graded sands or of massive sediments and an upper part composed of normally graded sediments.

A massive appearance is observed in approximately $45 \%$ of the investigated sites (Figs. 3 and 4). These deposits lack clear change in their grain size or macroscopically visible laminations. The massive structure is observed in deposits of various thickness, grain size (both in sand and muds) and distance from the shoreline. The massive layers are more common in areas with smaller runup (more than 50\%) than in the regions with a higher runup (approximately $40 \%$ ). A normal grading (fining upward) is the most common appearance of the IOT layers. Along the Phang Nga coast it is found in almost $70 \%$ of the sites with a low runup height and in almost all of the sites with a higher runup (Table 1). A reverse grading is found only in 2 trenches located less than $200 \mathrm{~m}$ from the shoreline, forming the lowermost part of the tsunami deposits. Frequently, tsunami deposits are 
Table 1. Comparison of selected IOT deposits characteristics from Phang Nga province transects of tsunami runup height $<6 \mathrm{~m}$ and $>6 \mathrm{~m}$.

\begin{tabular}{|c|c|c|}
\hline & runup $<6 \mathrm{~m}$ & runup $>6 \mathrm{~m}$ \\
\hline transect No (Figs. 3 and 4) & $2,3,4,8$ & $1,5,6,7$ \\
\hline $\begin{array}{l}\text { No of samples analysed } \\
\text { for grain size }\end{array}$ & 27 & 64 \\
\hline average thickness $[\mathrm{cm}]$ & 8.5 & 11.4 \\
\hline maximum thickness $[\mathrm{cm}]$ & 35 & 40 \\
\hline $\begin{array}{l}\text { most common trend of } \\
\text { landward tsunami deposits } \\
\text { thickness changes }\end{array}$ & $\begin{array}{l}\text { one to three maxima: approximately } \\
100 \mathrm{~m} \text { from shoreline and }>150 \mathrm{~m} \\
\text { from the shoreline }\end{array}$ & $\begin{array}{l}\text { maximum in approximately } 1 / 3 \\
\text { of the inundation distance or relatively } \\
\text { uniform thick sediment blanket } \\
\text { throughout the inundation zone }\end{array}$ \\
\hline $\begin{array}{l}\text { average and maximum } \\
\text { (in brackets) \% mud }\end{array}$ & $1.5(20.3)$ & $2.8(67.9)$ \\
\hline $\begin{array}{l}\text { average and maximum } \\
\text { (in brackets) \% gravel }\end{array}$ & $28.7(84.9)$ & $11.8(57.1)$ \\
\hline $\begin{array}{l}\text { range and average value } \\
\text { (in brackets) of mean grain } \\
\text { size [phi] }\end{array}$ & $0.6-5.6(3.14)$ & $0.02-5.8(2.38)$ \\
\hline $\begin{array}{l}\text { range and average value } \\
\text { (in brackets) of grain size } \\
\text { sorting [phi] }\end{array}$ & $0.7-1.99(1.33)$ & $0.46-3.11(1.33)$ \\
\hline $\begin{array}{l}\text { range and average value } \\
\text { (in brackets) of grain size } \\
\text { skewness [phi] }\end{array}$ & $-0.55-2.3(1.0)$ & $-1.4-4.7(0.81)$ \\
\hline $\begin{array}{l}\text { range and average value } \\
\text { (in brackets) of grain size } \\
\text { kurtosis [phi] }\end{array}$ & $2.5-16.6(8.49)$ & $1.4-60.9(8.92)$ \\
\hline $\begin{array}{l}\text { \% of sites with multiple } \\
\text { layers within tsunami deposits }\end{array}$ & $10 \%$ & $41 \%$ \\
\hline$\%$ of sites with massive layers* & 54 & 41 \\
\hline $\begin{array}{l}\% \text { of sites with normally } \\
\text { graded layers* }\end{array}$ & 68 & 97 \\
\hline$\%$ of sites with laminated layers* & 10 & 25 \\
\hline $\begin{array}{l}\text { preserved surface } \\
\text { sedimentary bedforms }\end{array}$ & no & ripples and circular hollows \\
\hline internal erosional contacts & no & in approximately $15 \%$ of sites \\
\hline
\end{tabular}

*at particular sites several layers of various types may occur; thus, the sum of massive, laminated and normally graded layers may be higher than $100 \%$.

laminated. In the areas with higher runup more than $25 \%$ of the sites reveal a plane lamination. In the sites with lower runup and in the sites located more than $450 \mathrm{~m}$ from the coastline the plane lamination is less common. Cross lamination is less frequent and is found in a few sites close to the shoreline. The scour and fill structures recording two distinct depositional events are found in 5 trenches located within $200 \mathrm{~m}$ of the coastline in areas with a runup $>6 \mathrm{~m}$.

\subsection{Tsunami deposit grain size distribution}

The grain sizes of the tsunami deposits range from mud to boulders; however, the sand fraction dominates (Fig. 2). On average, the mud content is approximately $2 \%$ and rarely reaches more than $10 \%$. The gravel fraction on average comprises $15 \%$ of the deposits, and in several samples, the gravel content is greater than $80 \%$, with only a small sand admixture. Sometimes, larger pebbles and cobbles existed in the deposits (Fig. 2(B)). The boulders found at Pakarang Cape and elsewhere in the studied region are described in detail by Goto et al. (2007) and Yawsangratt et al. (2009) and are not described here.

The grain size distributions of the analysed samples
(Figs. 3-6 and 8, Table 1) revealed large variations. The mean grain size ranges from -0.61 phi (very coarse sand) to 5.78 phi (coarse silt). However, the mean for most of the samples was in medium, fine and very fine sand classes. The IOT deposits range from very poorly sorted to well sorted, but more than $50 \%$ of the analysed samples fall in the poorly sorted sediment class. Skewness describes the asymmetry of the grain size distribution. The tsunami deposits represent the entire range of grain size distributions, from very coarse skewed to very fine skewed. Kurtosis defines the peakedness of the size distribution. The studied sediments also represent the entire range of grain size distributions, from very platycurtic to very leptokurtic distributions; the leptokurtic and very leptokurtic distribution types are the most common. From the four statistical parameters, only the mean and the sorting are slightly correlated (the correlation coefficient is 0.56 ). The finer sediments usually are more poorly sorted.

The vertical changes in the grain size are studied in 23 trenches (Figs. 3-5). The most common vertical change is normal grading, which is present in 19 trenches. The 
tsunami deposits may consist of one normally graded layer, or they may consist of multiple layers, with one or two normally graded layers (Fig. 5). In some of the IOT deposits, no clear vertical gradation was observed, or the gradation was inverse.

The landward trends in the sediment grain size are variable (Figs. 3, 4 and 6), although there is a very general fining landward if the complete dataset is analysed (Fig. 8). The fining is not linear. It is visible if the maximum and minimum sizes are taken into account. The mean grain sizes in the coarse and medium sands dominate in the first $100 \mathrm{~m}$ from the shoreline. Further landward, the maximum mean grain size is in the medium and the fine sand classes. The mean grain sizes in the very fine sand and silt fractions are observed no closer than approximately $100 \mathrm{~m}$ to the shoreline.

The grain size distribution profiles are presented for transects 4 (runup $2.9 \mathrm{~m}$ ) and 5 (runup $7.7 \mathrm{~m}$ ) in Fig. 6, which includes beach samples and some soil samples. In both transects, general fining landward is visible. The beach samples and some of the soil samples present quite different grain size distributions from the tsunami deposits. This finding may suggest that most of the tsunami deposits come from other sources (e.g., seafloor erosion). However, the beach samples may not be representative, as they were sampled after the tsunami. In both transects (Fig. 6), the samples of the tsunami deposits collected closest to the shoreline sites (less than $100 \mathrm{~m}$ ) are coarser and are similar to underlying soils. The more landward deposits are characterised by relatively similar distributions, although the variations were recorded particularly in trenches, where fining upward is common.

The IOT deposit grain sizes in the Phang Nga transects do not show a clear relation to the tsunami runup heights. The ranges of the observed values of the grain size statistics and their horizontal trends are similar for various runup values (Figs. 3 and 4, Table 1).

\section{Discussion}

\subsection{IOT deposits characteristics}

The studied deposits reveal many characteristics typical for the recent tsunami deposits known from other case studies (Table 2). For instance, the thickness of the tsunami deposits, in the range of a few $\mathrm{mm}$ to approximately $40 \mathrm{~cm}$ and being approximately $10 \mathrm{~cm}$ on average, is very similar to those reported from the adjacent areas (Hori et al., 2007; Fujino et al., 2010), as well as from the other areas affected by the IOT (e.g., Moore et al., 2006) or other tsunamis (e.g., Gelfenbaum and Jaffe, 2003). This study found common features such as normally graded and massive layers. However, as a massive structure is observed on the basis of a macroscopic assessment in approximately $45 \%$ of the investigated sites, it appears that if investigated in detail through high resolution grain size analyses, sediment peels or X-ray pictures, they could appear to be graded or laminated in many cases (Choowong et al., 2008a). The basal sharp contact is also a common feature, although in the studied cases, it is not often of erosional character, as reported from other studies (Peters and Jaffe, 2010).

Several characteristics represented in the studied deposits were also found elsewhere, but they are not considered in common reviews as the most typical characteristics of tsunami deposits. For instance, parallel lamination was found relatively frequently, it already has been recorded in several previous studies of tsunami deposits (Srinivasalu $e t$ al., 2007), however it is often considered to be a typical feature of storm deposits (Morton et al., 2007). Occasionally, layers with inverse grading have also been reported (Naruse et al., 2010), and such layers were also found in this study.

There is also a group of features considered to be typical for tsunami deposits and being rare or absent in this study. For example, the common mud cups and rip-up clasts (Goff et al., 2001; Gelfenbaum and Jaffe, 2003) require a certain source of sediments (mud) as well as certain erosional conditions of cohesive soil or of mud substratum. In the present case, both are rare-sand is the dominant sediment source for the tsunami deposits, and the onshore erosion took place mostly on sandy soil, which does not favour production of rip-up clasts.

Some of the features associated with typical tsunami deposits were not found in this study. One such feature is soft sediment deformation, which was reported in several tsunami deposits worldwide (Van Loon, 2009). The sediment deformations were also found in the IOT deposits in Thailand in the form of truncated flame structures, but only in one unique setting (Matsumoto et al., 2008). Another feature not found in the studied IOT deposits is internal mud layering, which had been identified in the 1998 Papua New Guinea tsunami (Gelfenbaum and Jaffe, 2003).

The composition of the tsunami deposits is not a universal feature because it largely depends on the available source sediments for transport. Thus, if well-sorted dune sand is the unique source sediment, then the tsunami deposits will be of a similar type (Singarasubramanian et al., 2006). However, if the source is composed of various sediments, then the resulting deposits will be variable and poorly sorted. The most likely sediment sources in the present case are the beach and the shallow part of continental shelf. The beach sands in the studied region are in the range of fine to very coarse sands, with the finest sediments present at the high tide level and the coarsest at the low tide level (Grzelak et al., 2009). The continental shelf down to $20 \mathrm{~m}$ is covered with mud (mostly silt), fine to very coarse sand and occasionally boulders (Di Geronimo et al., 2009; Feldens et al., 2009, 2012). Beach and the inner shelf areas potentially offer all of the grain sizes observed in the onshore tsunami deposits and are variable enough to explain the very poor sediment sorting. However, the beach samples collected shortly after the tsunami may not be a good representation of the pretsunami beach. Grzelak et al. (2009) compared beach samples taken from three beaches in Thailand: Tri Trang, Patong and a beach in northern Kho Khao Island. They compared the samples taken at the low tide line, mean sea level and high water line and at various time points - shortly after the tsunami (February 2005) and in subsequent Februaries (2006, 2007 and 2008). The beach sediments collected shortly after the tsunami were coarser, more poorly sorted and more negatively skewed than those in the following years, which likely represent the pre-tsunami conditions. 
Table 2. Tsunami deposit identification criteria based on the compilation of recent tsunami deposits studies from Peters and Jaffe (2010) compared to the present case study.

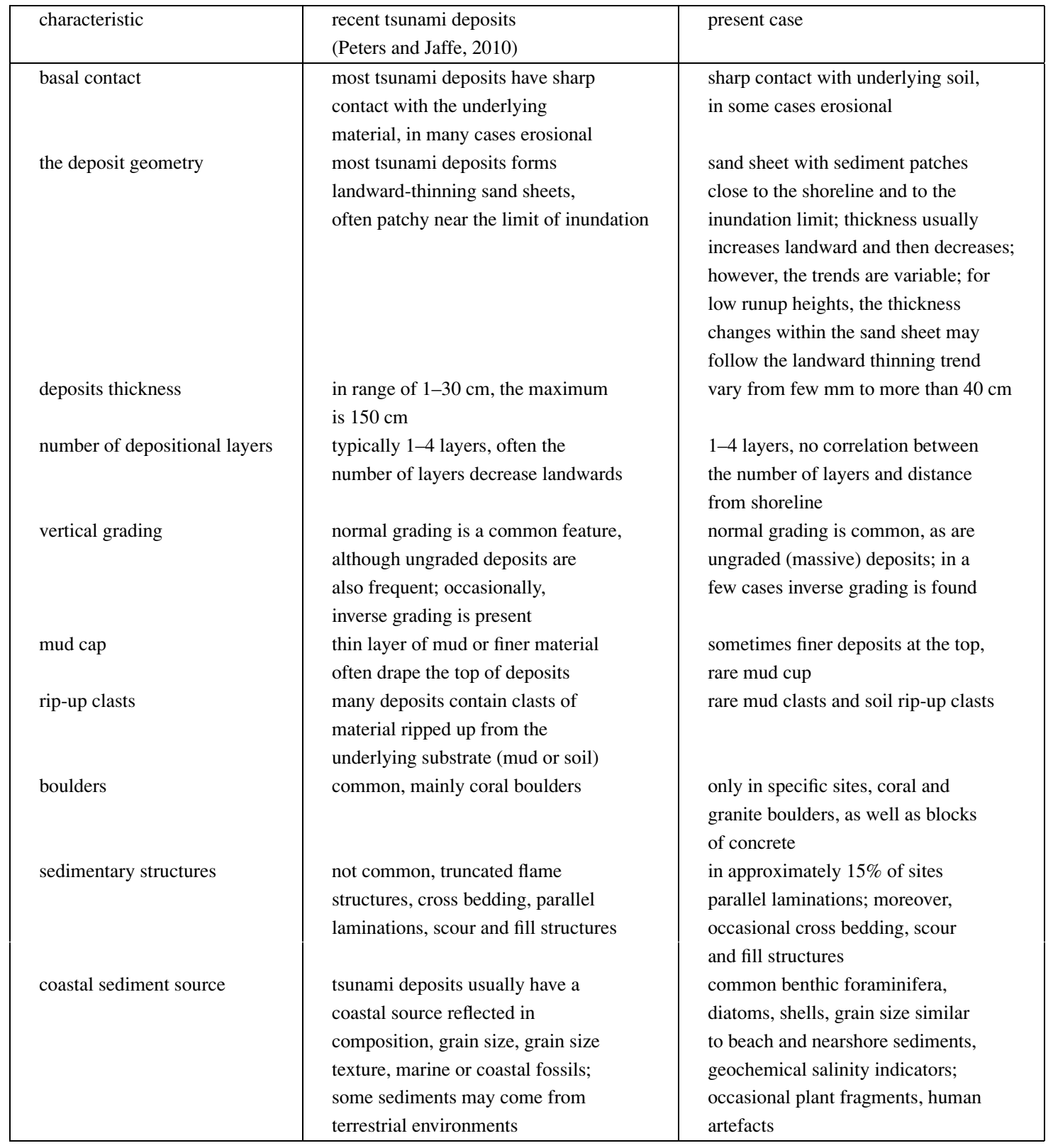

Probably the most commonly reported characteristic of the tsunami deposits, which is not supported by the data in this study, is the landward thinning of the deposits (Dawson and Shi, 2000; Morton et al., 2007). The recent studies contain many examples of thickness trends in the tsunami deposits, which do not follow the landward thinning trend (Moore et al., 2006; Hori et al., 2007; Fujino et al., 2008; Goto et al., 2008). However, in most cases, the deviations from the trend were explained by the role of the local relief, plant cover, etc. (Hori et al., 2007). Because studies of the modern deposits often focus on one or a few transects, it is difficult to determine if a certain transect is an "exception" or represents the overall distribution of deposits. In the dataset of this study, the effect of the local morphology is evident (i.e., accumulations in front of scarps). However, from the analysis of various transects, it seems that most of them do not reveal typical tsunami deposit thickness trends, even without major changes in the topography. In most of the sites, the maximum accumulation of the deposits is located approximately 100 to $300 \mathrm{~m}$ inland. Many of the tsunami deposit thickness transects reported in the literature also show the maximum deposition located some distance inland (Moore et al., 2006).

In the case of the commonly reported landward fining trend in tsunami deposits, a problem of the methodological approach appears. In many works, the bulk grain size of the tsunami deposits is analysed. Yet, several layers interpreted to be from various runups and even backwash phases are also reported. The bulk grain size analyses are an average of depositional effects from several different events, even as contrasting as uprush and backwash. In some places, many layers are preserved, and in others, just one is preserved; thus, it is likely that in some cases, the averaged record from several different events (e.g., runups, backwash) is 
compared with a depositional record of just one event. If the coastal zone is the major source of the sediments, then the overall landward fining trend would be expected and is indeed observed in the present study, although some of the transects exhibit significant variability.

\subsection{Tsunami deposits in areas of various runup heights}

The studied transects from relatively similar coasts of Phang Nga province, allowed for the rough comparison of an impact of tsunami size on sedimentation. This study consideres the tsunami runup height as an indicator of the tsunami size, as in the available data on tsunami height (Tsuji et al., 2006) suggests that high runup was not only due to topographic effect. The available data demonstrates that the available sediment sources for the compared studied sites are similar.

The comparison of the IOT deposits in the areas of the two preselected classes of runup heights is shown in Table 1. Most of the considered characteristics reveal some differences between the groups. The first significant difference is with regards to the quantity of the sediments deposited in various areas (as exemplified by the average IOT deposit thickness; thicker deposits exist in the areas of greater runup) and the way the deposits are distributed landward. In the case of the smallest runup, most of the deposits are left closer to the shoreline, and then the sandy layer generally decreases landward. With the higher runups, the accumulation is shifted landward. These finding may be explained by the bigger size of tsunami wave being capable of eroding more material over a larger area (both offshore and onshore) and of transporting more sediments, as well as losing the energy necessary to keep the sediments in transport further onshore. The limitation for the suggested relationship is the amount of available source sediments for the erosion, such as with rocky coastlines.

If the proposed explanation is correct, then the sediment properties should also vary between the areas of various runup heights. In comparing the grain size statistics, such as mean or kurtosis, there is no difference between the various areas. However, the areas of greater runup appear to be enriched in the finest fraction. This trend is emphasised by much higher maximum values of mud content, sorting and skewness. An explanation for this could be provided by the observation of the offshore sediment distribution. Mud is locally common on the seafloor at a water depth greater than $5 \mathrm{~m}$ (Di Geronimo et al., 2009; Feldens et al., 2009, 2012). Larger quantities of mud in the onshore tsunami deposits on land may suggest that the seafloor erosion resulted from the bigger tsunami (as evidenced by a higher runup), is more efficient relative to a smaller tsunami (with smaller runup).

Additional differences in the IOT deposits in the areas of lower and higher tsunami runups include the domination of normally graded layers and laminated layers and the presence of internal erosional contacts in the region with a higher runup. The more frequent normally graded sediments may be explained by deeper flooding from the tsunami. The deeper water depth offers the time necessary for the differential settling of various grain sizes. Larger velocities may cause the tsunami to erode not only the onshore soils but also the sediments already deposited by the tsunami.

\subsection{Insights into sedimentary processes during the IOT}

Taking into account the large variability in the tsunami deposits and the complexity of the tsunami flooding, as evidenced by the available video footage and eyewitnesses records (Choowong et al., 2008b), the complete sedimentation history is unlikely to be reconstructed based on the evidence presented here. The accounts of the eyewitnesses vary with regards to the number of waves and the wave intensity (Mård Karlsson et al., 2009). Furthermore, the waves recorded as a single wave at the tidal gauges (Tsuji et al., 2006) appeared at some portions of the coast to be a series of at least two waves (Mård Karlsson et al., 2009). In many areas, the water ponded after the first flooding and did not withdraw until the end of the tsunami wave train (Choowong et al., 2008b). This makes it difficult and speculative to connect particular sedimentary layers to a particular tsunami wave or its phase (runup and backwash). The physical features preserved in the deposits directly represent the physics of the sediment movement that existed at the final moments of the deposition, so it is not possible to directly interpret the sediment transport mode (see Shanmugam (2012) for further discussion). Several authors suggested the presence of backwash deposits within multilayered, normally graded tsunami deposits (Hori et al., 2007; Paris et al., 2007), but unless the interpretation is supported by sedimentary structures formed during the backflow (Choowong et al., 2008a), such an interpretation may be speculative as well. The backwash was concentrated in most of the IOT-affected regions as a kind of channelised flow (Umitsu et al., 2007; Fagherazzi and Du, 2008) and was more likely to erode than to deposit a new sedimentary layer.

The observed sedimentary deposits allowed to suggest that the sedimentation took place during several phases (inundations), producing separate layers. Common presence of fining upward deposits suggests suspension settling to be dominating depositional process. The relatively common massive layers may be the result of hyperconcentrated flow but also may be the result of the limited variability within the sediment grain size and of the short settling period, which is too short to permit grain size gradation. Reverse gradation and planar lamination of some deposits imply also direct deposition from bed load. Moreover, many local features-for instance: lee side depositional ridges, rows of vortex-generated circular hollows, local rippled surfaces, suggest complex tsunami flow pattern.

\section{Conclusion}

This paper provides new, original data on the development of the tsunami deposits resulting from a large tsunami in areas of various tsunami runup heights. The deposits are characterised by a thickness as great as $40 \mathrm{~cm}$, with variable locations of the areas of maximum accumulation (but often not next to the shoreline) and basal sharp contacts, frequent massive, normally graded or laminated layers and general landward fining of the tsunami deposit grain size. The comparison of the deposits with the typical features of tsunami deposits reveals that simple continuous landward thinning trend of the tsunami layer may not really exist. 
The tsunami size (presented as the tsunami runup height) appears to be reflected in the resulting deposits for comparable parts of coastline. A larger tsunami forms thicker deposits with the maximum accumulation located further inland. These deposits are enriched with sediment grain size fractions more common in deeper waters (in this case, the mud fraction likely came from water deeper than $5 \mathrm{~m}$ ), and because of the bigger flow depth, the normally graded layers are more common.

Acknowledgments. The study was supported by Adam Mickiewicz University in Poznań, Poland and Department of Mineral Resources in Bangkok, Thailand. The authors appreciate to Mr. Somsak Potisat and to Mr. Apitchai Chvajarernpun-the Directors General of the Department of Mineral Resurces of Kingdom of Thailand and the DMR's Chief of Foreign Affairs, Dr. Sommai Techawan. We acknowledge also to all colleagues who helped us in lab or field work, in particular to Radosław Jagodziński and Tinnakorn Tatong. We thank Shigehiro Fujino, an anonymous reviewer and the editor Yuichi Nishimura, for constructive critical comments.

\section{References}

Alam, S., Characterization of Tsunami Deposits at the Andaman Coast of Thailand, 52 pp., Lambert Academic Publishing, Saarbrücken, 2010.

Bahlburg, H. and R. Weiss, Sedimentology of the December 26, 2004, Sumatra tsunami deposits in eastern India (Tamil Nadu) and Kenya, Int. J. Earth Sci., 96, 1195-1209, 2007.

Bishop, P., D. Sanderson, J. Hansom, and N. Chaimanee, Age-dating of tsunami deposits: lessons from the 26 December 2004 tsunami in Thailand, Geogr. J., 171, 379-384, 2005.

Blott, S. J. and K. Pye, Gradistat: A grain-size distribution and statistics package for the analysis of unconsolidated sediments, Earth Surf. Process. Landf., 26, 1237-1248, 2001.

Boszke, L., A. Kowalski, W. Szczuciński, G. Rachlewicz, S. Lorenc, and J. Siepak, Assessment of mercury mobility and bioavailability by fractionation method in sediments from coastal zone inundated by the $26 \mathrm{De}-$ cember 2004 tsunami in Thailand, Environ. Geol., 51, 527-536, 2006.

Bourgeois, J., Geologic records and effects of tsunamis, in The Sea, volume 15: Tsunamis, edited by A. R. Robinson and E. N. Bernard, pp. 53-91, Harvard University Press, Cambridge, 2009.

Bourgeois, J., C. Petroff, H. Yen, V. Titov, C. E. Synolakis, B. Benson, J. Kuroiwa, J. Lander, and E. Norabuena, Geologic Setting, Field Survey and Modeling of the Chimbote, Northern Peru, Tsunami of 21 February 1996, Pure Appl. Geophys., 154, 513-540, 1999.

Brill, D., H. Brückner, K. Jankaew, D. Kelletat, A. Scheffers, and S. Scheffers, Potential predecessors of the 2004 Indian Ocean TsunamiSedimentary evidence of extreme wave events at Ban Bang Sak, SW Thailand, Sediment. Geol., 239, 146-161, 2011.

Chagué-Goff, C., Chemical signatures of palaeotsunamis: A forgotten proxy?, Mar. Geol., 271, 67-71, 2010.

Chagué-Goff, C., J.-L. Schneider, J. R. Goff, D. Dominey-Howes, and L. Strotz, Expanding the proxy toolkit to help identify past events: Lessons from the 2004 Indian Ocean Tsunami and the 2009 South Pacific Tsunami, Earth-Sci. Rev., 107, 107-122, 2011.

Choowong, M., N. Murakoshi, K. Hisada, P. Charusiri, V. Daorerk, T. Charoentitirat, V. Chutakositkanon, K. Jankaew, and P. Kanjanapayont, Erosion and deposition by the 2004 Indian Ocean tsunami in Phuket and Phang-nga Provinces, Thailand, J. Coast. Res., 23, 1270-1276, 2007.

Choowong, M., N. Murakoshi, K. Hisada, T. Charoentitirat, P. Charusiri, S. Phantuwongraj, P. Wongkok, A. Choowong, R. Subsayjun, V. Chutakositkanon, K. Jankaew, and P. Kanjanapayont, Flow conditions of the 2004 Indian Ocean tsunami in Thailand, inferred from capping bedforms and sedimentary structures, Terra Nova, 20, 141-149, 2008a.

Choowong, M., N. Murakoshi, K. Hisada, P. Charusiri, T. Charoentitirat, V. Chutakositkanon, K. Jankaew, P. Kanjanapayont, and S. Phantuwongraj, 2004 Indian Ocean tsunami inflow and outflow at Phuket, Thailand, Mar. Geol., 248, 179-192, 2008b.

Clague, J. J., P. T. Bobrowsky, and I. Hutchinson, A review of geological records of large tsunamis at Vancouver Island, British Columbia, and implications for hazard, Quat. Sci. Rev., 19, 849-863, 2000.

Dawson, A. and S. Shi, Tsunami deposits, Pure Appl. Geophys., 157, 875-
897, 2000.

Dawson, A. G., S. Shi, S. Dawson, T. Takahashi, and N. Shuto, Coastal sedimentation associated with the June 2nd and 3rd, 1994 tsunami in Rajegwesi, Java, Quat. Sci. Rev., 15, 901-912, 1996.

Di Geronimo, I., M. Choowong, and S. Phantuwongraj, Geomorphology and superficial bottom sediments of Khao Lak coastal area (SW Thailand), Polish J. Environ. Stud., 18, 111-121, 2009.

Fagherazzi, S. and X. Du, Tsunamigenic incisions produced by the December 2004 earthquake along the coasts of Thailand, Indonesia and Sri Lanka, Geomorphology, 99, 120-129, 2008.

Feldens, P., K. Schwarzer, W. Szczuciński, K. Stattegger, D. Sakuna, and P. Somgpongchaiykul, Impact of 2004 Tsunami on seafloor morphology and offshore sediments, Pakarang Cape, Thailand, Polish J. Environ. Stud., 18, 63-68, 2009.

Feldens, P., K. Schwarzer, D. Sakuna, W. Szczuciński, and P. Sompongchaiyakul, Sediment distribution on the inner continental shelf off Khao Lak (Thailand) after the 2004 Indian Ocean tsunami, Earth Planets Space, 64, 875-887, 2012.

Fujino, S., H. Naruse, A. Suphawajruksakul, T. Jarupongsakul, M. Murayama, and T. Ichihara, Thickness and grain-size distribution of Indian Ocean tsunami deposits at Khao Lak and Phra Thong Island, southwestern Thailand, in Tsunamiites-Features and Implications, edited by T. Shiki, Y. Tsuji, T. Yamazaki, and K. Minoura, pp. 123-132, Elsevier B.V., Amsterdam, 2008.

Fujino, S., H. Naruse, D. Matsumoto, T. Jarupongsakul, A. Sphawajruksakul, and N. Sakakura, Stratigraphic evidence for pre-2004 tsunamis in southwestern Thailand, Mar. Geol., 262, 25-28, 2009.

Fujino, S., H. Naruse, D. Matsumoto, N. Sakakura, A. Suphawajruksakul, and T. Jarupongsakul, Detailed measurements of thickness and grain size of a widespread onshore tsunami deposit in Phang-nga Province, southwestern Thailand, Island Arc, 19, 389-398, 2010.

Gelfenbaum, G. and B. Jaffe, Erosion and sedimentation from the 17 July, 1998 Papua New Guinea Tsunami, Pure Appl. Geophys., 160, 19691999, 2003.

Goff, J., C. Chagué-Goff, and S. Nichol, Palaeotsunami deposits: A New Zealand perspective, Sediment. Geol., 143, 1-6, 2001.

Goff, J., C. Chagué-Goff, S. Nichol, B. Jaffe, and D. Dominey-Howes, Progress in palaeotsunami research, Sediment. Geol., 243-244, 70-88, 2012.

Goto, K., S. A. Chavanich, F. Imamura, P. Kunthasap, T. Matusi, K. Minoura, D. Sugawara, and H. Yanagisawa, Distribution, origin and transport process of boulders deposited by the 2004 Indian Ocean tsunami at Pakarang Cape, Thailand, Sediment. Geol., 202, 821-837, 2007.

Goto, K., F. Imamura, N. Keerthi, P. Kunthasap, T. Matsui, K. Minoura, A. Ruangrassamee, D. Sugawara, and S. Supharatid, Distribution and significance of the 2004 Indian Ocean tsunami deposits: initial results from Thailand and Sri Lanka, in Tsunamiites-Features and Implications, edited by T. Shiki, Y. Tsuji, T. Yamazaki, and K. Minoura, pp. 105-122, Elsevier B.V., Amsterdam, 2008.

Goto, K., C. Chagué-Goff, S. Fujino, J. Goff, B. Jaffe, Y. Nishimura, B. Richmond, D. Sugawara, W. Szczuciński, D. R. Tappin, R. C. Witter, and E. Yulianto, New insights of tsunami hazard from the 2011 Tohokuoki event, Mar. Geol., 290, 46-50, 2011.

Goto, K., J. Takahashi, and S. Fujino, Variations in the 2004 Indian Ocean tsunami deposits thickness and their preservation potential, southwestern Thailand, Earth Planets Space, 64, 923-930, 2012.

Grzelak, K., L. Kotwicki, and W. Szczuciński, Monitoring of Sandy Beach Meiofaunal Assemblages and Sediments after the 2004 Tsunami in Thailand, Polish J. Environ. Stud., 18, 43-51, 2009.

Hawkes, A. D., M. Bird, S. Cowie, C. Grundy-Warr, B. P. Horton, A. T. Shau Hwai, L. Law, C. Macgregor, J. Nott, J. E. Ong, J. Rigg, R. Robinson, M. Tan-Mullins, T. T. Sa, Z. Yasin, and L. W. Aik, Sediments deposited by the 2004 Indian Ocean tsunami along the Malaysia-Thailand peninsula, Mar. Geol., 242, 169-190, 2007.

Higman, B. and J. Bourgeois, Deposits of the 1992 Nicaragua tsunami, in Tsunamiites-Features and Implications, edited by T. Shiki, Y. Tsuji, T. Yamazaki, and K. Minoura, pp. 81-103, Elsevier B.V., Amsterdam, 2008.

Hori, K., R. Kuzumoto, D. Hirouchi, M. Umitsu, N. Janjirawuttikul, and B. Patanakanog, Horizontal and vertical variation of 2004 Indian tsunami deposits: An example of two transects along the western coast of Thailand, Mar. Geol., 238, 163-172, 2007.

Intergovernmental Oceanographic Commission, Tsunami Glossary, 40 pp., IOC Technical Series 85, Paris, UNESCO, 2008.

Jaffe, B. E. and G. Gelfenbaum, A simple model for calculating tsunami flow speed from tsunami deposits, Sediment. Geol., 200, 347-361, 2007. 
Jagodziński, R., B. Sternal, W. Szczuciński, and S. Lorenc, Heavy minerals in 2004 tsunami deposits on Kho Khao Island, Thailand, Polish J. Environ. Stud., 18, 103-110, 2009.

Jankaew, K., B. F. Atwater, Y. Sawai, M. Choowong, T. Charoentitirat, M. E. Martin, and A. Prendergast, Medieval forewarning of the 2004 Indian Ocean tsunami in Thailand, Nature, 455, 1228-1231, 2008.

Jankaew, K., M. E. Martin, Y. Sawai, and A. L. Prendergast, Sand sheets on a beach-ridge plain in Thailand: Identification and dating of tsunami deposits in a far-field tropical setting, in The Tsunami Threat - Research and Technology, edited by N.-A. Mörner, pp. 299-324, InTech, Rijeka, 2011.

Kawata, T. et al., Comprehensive analysis of the damage and its impact on coastal zones by the 2004 Indian Ocean tsunami disaster report, Disaster Prev. Res. Inst., Kyoto, Japan, 2005. (Available at http://www.tsunami.civil.tohoku.ac.jp/sumatra2004/report.html.)

Kelletat, D., S. R. Scheffers, and A. Scheffers, Field signatures of the SE-Asian mega-tsunami along the west coast of Thailand compared to Holocene Paleo-Tsunami from the Atlantic region, Pure Appl. Geophys., 164, 413-431, 2007.

Kench, P. S., R. F. McLean, R. W. Brander, S. L. Nichol, S. G. Smithers, M. R. Ford, K. E. Parnell, and M. Aslam, Geological effects of tsunami on mid-ocean atoll islands: The Maledives before and after the Sumatran tsunami, Geology, 34, 177-180, 2006.

Kokociński, M., W. Szczuciński, A. Zgrundo, and A. Ibragimow, Diatom assemblages in 26 December 2004 tsunami deposits from coastal zone of Thailand as sediment provenance indicators, Polish J. Environ. Stud., 18, 93-101, 2009.

Kozak, L., P. Niedzielski, and W. Szczuciński, The methodology and results of determination of inorganic arsenic species in mobile fractions of tsunami deposits by hyphenated technique of HPLC-HG-AAS, Int. J. Environ. Anal. Chem., 88, 989-1003, 2008.

Lay, T., H. Kanamori, C. J. Ammon, M. Nettles, S. N. Ward, R. C. Aster, S. L. Beck, S. L. Bilek, M. R. Brudzinski, R. Butler, H. R. DeShon, G. Ekström, K. Satake, and S. Sipkin, The great Sumatra-Andaman Earthquake of 26 December 2004, Science, 308, 1127-1133, 2005.

Mård Karlsson, J., A. Skelton, M. Sandén, M. Ioualalen, N. Kaewbanjak, N. Pophet, J. Asavanant, and A. von Matern, Reconstructions of the coastal impact of the 2004 Indian Ocean tsunami in the Khao Lak area, Thailand, J. Geophys. Res., 114, C10023, 2009.

Matsumoto, D., H. Naruse, S. Fujino, A. Surphawajruksakul, T. Jarupongsakul, N. Sakakura, and M. Murayama, Truncated flame structures within a deposit of the Indian Ocean Tsunami: Evidence of synsedimentary deformation, Sedimentology, 55, 1559-1570, 2008.

Minoura, K., F. Imamura, T. Takahashi, and N. Shuto, Sequence of sedimentation processes caused by the 1992 Flores tsunami: Evidence from Babi Island, Geology, 25, 523-526, 1997.

Moore, A., Y. Nishimura, G. Gelfenbaum, T. Kamataki, and R. Triyono, Sedimentary deposits of the 26 December 2004 tsunami on the northwest coast of Aceh, Indonesia, Earth Planets Space, 58, 253-258, 2006.

Moore, A., J. Goff, B. G. McAdoo, H. M. Fritz, A. Gusman, N. Kalligeris, K. Kalsum, A. Susanto, D. Suteja, and C. E. Synolakis, Sedimentary deposits from the 17 July 2006 western Java tsunami, Indonesia: Use of grain size analyses to assess tsunami flow depth, speed, and traction carpet characteristics, Pure Appl. Geophys., 168, 1951-1961, 2011.

Morton, R. A., G. Gelfenbaum, and B. E. Jaffe, Physical criteria for distinguishing sandy tsunami and storm deposits using modern examples, Sediment. Geol., 200, 184-207, 2007.

Morton, R. A., J. R. Goff, and S. L. Nichol, Hydrodynamic implications of textural trends in sand deposits of the 2004 tsunami in Sri Lanka, Sediment. Geol., 207, 56-64, 2008.

Nanayama, F. and K. Shigeno, Inflow and outflow facies from the 1993 tsunami in southwest Hokkaido, Sediment. Geol., 187, 139-158, 2006.

Nanayama, F., R. Furukawa, K. Shigeno, A. Makino, Y. Soeda, and Y. Igarashi, Nine unusually large tsunami deposits from the past 4000 years at Kiritappu marsh along the southern Kuril Trench, Sediment. Geol., 200, 275-294, 2007.

Naruse, H., S. Fujino, A. Suphawajruksakul, and T. Jarupongsakul, Features and formation processes of multiple deposition layers from the 2004 Indian Ocean Tsunami at Ban Nam Kem, southern Thailand, Island Arc, 19, 399-411, 2010.

Nichol, S. L. and P. S. Kench, Sedimentology and preservation potential of carbonate sand sheets deposited by the December 2004 Indian Ocean tsunami: South Baa Atoll, Maledives, Sedimentology, 55, 1173-1187, 2008.

Nishimura, Y. and N. Miyaji, Tsunami deposits from the 1993 Southwest Hokkaido earthquake and the 1640 Hokkaido Komagatake eruption,
Northern Japan, Pure Appl. Geophys., 144, 719-734, 1995.

Paris, R., F. Lavigne, P. Wassmer, and J. Sartohadi, Costal sedimentation associated with the December 26, 2004 tsunami in Lhok Nga, west Banda Aceh (Sumatra, Indonesia), Mar. Geol., 238, 93-106, 2007.

Paris, R., P. Wassmer, J. Sartohadi, F. Lavigne, B. Barthomeuf, E. Desgages, D. Grancher, P. Baumert, F. Vautier, D. Brunstein, and C. Gomez, Tsunami as geomorphic crises: Lessons from the December 26, 2004 tsunami in Lhok Nga, West Banda Aceh (Sumatra, Indonesia), Geomorphology, 104, 59-72, 2009.

Peters, R. and B. Jaffe, Identification of tsunami deposits in the geologic record: developing criteria using recent tsunami deposits, U.S. Geological Survey Open-File Report, 2010-1239, 39 pp, 2010.

Razzhigaeva, N. G., L. A. Ganzei, T. A. Grebennikova, E. D. Ivanova, and V. M. Kaistrenko, Sedimentation Particularities during the Tsunami of December 26, 2004, in Northern Indonesia: Simelue Island and Medan Coast of Sumatra Island, Oceanology, 46, 929-945, 2006.

Richmond, B. M., B. E. Jaffe, G. Gelfenbaum, and R. A. Morton, Geologic Impacts of the 2004 Indian Ocean Tsunami on Indonesia, Sri Lanka, and the Maldives, Zeitschrift für Geomorphologie, 146, 235-251, 2006.

Sato, H., T. Shimamoto, A. Tsutsumi, and E. Kawamoto, Onshore tsunami deposits caused by the 1993 Southwest Hokkaido and 1983 Japan Sea earthquakes, Pure Appl. Geophys., 144, 693-717, 1995.

Sawai, Y., K. Jankaew, M. E. Martin, A. Prendergast, M. Choowong, and T. Charoentitirat, Diatom assemblages in tsunami deposits associated with the 2004 Indian Ocean tsunami at Phra Thong Island, Thailand, Mar. Micropaleontol., 73, 70-79, 2009.

Scheffers, A. and D. Kelletat, Sedimentological and geomorphologic tsunami imprints worldwide-a review, Earth-Sci. Rev., 63, 83-92, 2003.

Shanmugam, G., Process-sedimentological challenges in distinguishing paleo-tsunami deposits, Nat. Haz., 63, 5-30, 2012.

Shi, S., A. G. Dawson, and D. E. Smith, Coastal sedimentation associated with the December 12th, 1992 tsunami in Flores, Indonesia, Pure Appl. Geophys., 144, 525-536, 1995.

Shiki, T., Y. Tsuji, T. Yamazaki, and K. Minoura (eds.), TsunamiitesFeatures and Implications, 425 pp., Elsevier, 2008.

Singarasubramanian, S. R., M. V. Mukesh, K. Manoharan, S. Murugan, D. Bakkiaraj, and A. John Peter, Sediment characteristics of the M-9 tsunami event between Rameswaram and Thoothukudi, Gulf of Mannar, southeast coast of India, Sci. Tsunami Haz., 25, 160-172, 2006.

Siripong, A., Andaman seacoast of Thailand filed survey after the December 2004 Indian Ocean Tsunami, Earthq. Spectr., 22, 187-202, 2006.

Smith, D. E., I. D. L. Foster, D. Long, and S. Shi, Reconstructing the pattern and depth of flow onshore in a paleotsunami from associated deposits, Sediment. Geol., 200, 362-371, 2007.

Srinivasalu, S., N. Thangadurai, A. D. Switzer, V. Ram Mohan, and T. Ayyamperumal, Erosion and sedimentation in Kalpakkam (N Tamil Nadu, India) from the 26th December 2004 tsunami, Mar. Geol., 240, 65-75, 2007.

Subarya, C., M. Chlieh, L. Prawirodirdjo, J.-P. Avouac, Y. Bock, K. Sieh, A. J. Meltzner, D. H. Natawidjaja, and R. McCaffrey, Plate-boundary deformation associated with the great Sumatra-Andaman earthquake, Nature, 440, 46-51, 2006.

Switzer, A. D. and B. G. Jones, Large-scale washover sedimentation in a freshwater lagoon from the southeast Australian coast: Sea-level change, tsunami or exceptionally large storm?, Holocene, 18, 787-803, 2008 .

Szczuciński, W., The post-depositional changes of the onshore 2004 tsunami deposits on the Andaman Sea coast of Thailand, Nat. Haz., 60, 115-133, 2012.

Szczuciński, W., N. Chaimanee, P. Niedzielski, G. Rachlewicz, D. Saisuttichai, T. Tepsuwan, S. Lorenc, and J. Siepak, Environmental and geological impacts of the 26 December 2004 tsunami in coastal zone of Thailand-overview of some short and long-term effects, Polish J. Environ. Stud., 15, 793-810, 2006.

Szczuciński, W., P. Niedzielski, G. Rachlewicz, T. Sobczyński, A. Zioła, A. Kowalski, S. Lorenc, and J. Siepak, Contamination of tsunami sediments in a coastal zone inundated by the 26 December 2004 tsunami in Thailand, Environ. Geol., 49, 321-331, 2005.

Szczuciński, W., P. Niedzielski, L. Kozak, M. Frankowski, A. Zioła, and S. Lorenc, Effects of rainy season on mobilization of contaminants from tsunami deposits left in coastal zone of Thailand by the 26 December 2004 tsunami, Environ. Geol., 53, 253-264, 2007.

Tsuji, Y., Y. Namegaya, H. Matsumoto, S. I. Iwasaki, W. Kanbua, M. Sriwichai, and V. Meesuk, The 2004 Indian tsunami in Thailand. Surveyed runup heights and tide gauge records, Earth Planets Space, 58, 223- 
232,2006

Umitsu, M., C. Tanavud, and B. Patanakanog, Effects of landforms on tsunami flow in the plains of Banda Aceh, Indonesia, and Nam Khem, Thailand, Mar. Geol., 242, 141-153, 2007.

Van Loon, A. J., Soft-sediment deformation structures in siliciclastic sediments: an overview, Geologos, 15, 3-55, 2009.

Yawsangratt, S., W. Szczuciński, N. Chaimanee, R. Jagodziński, S. Lorenc, S. Chatprasert, D. Saisuttichai, and T. Tepsuwan, Depositional effects of 2004 tsunami and hypothetical paleotsunami near Thap Lamu Navy Base in Phang Nga Province, Thailand, Polish J. Environ. Stud., 18, 1723, 2009.
Yawsangratt, S., W. Szczuciński, N. Chaimanee, S. Chatprasert, W. Majewski, and S. Lorenc, Evidence of probable paleotsunami deposits on Kho Khao Island, Phang Nga Province, Thailand, Nat. Haz., 63, 151$163,2012$.

Zioła-Frankowska, A., M. Frankowski, W. Szczuciński, and J. Siepak, Analysis of labile aluminium form in grain size fractions of tsunami deposits in Thailand, Polish J. Environ. Stud., 18, 77-85, 2009.

W. Szczuciński (e-mail: witek@amu.edu.pl), G. Rachlewicz, N. Chaimanee, D. Saisuttichai, T. Tepsuwan, and S. Lorenc 